\title{
Reduction of Iron Oxide by Carbon in Stainless Steelmaking Slags
}

\author{
M. Divakar", M. Görnerup ${ }^{*+1}$ and A. K. Lahiri \\ *Department of Metallurgical and Materials Engineering, The University of Alabama, \\ Tuscaloosa, $A L$ 35487-0202, USA \\ **Uddeholm Technology AB, Uvåv. 2, S-68340, Uddeholm, Swéden. \\ Department of Metallurgy, Indian Institute of Science, Bangalore - 560 012, India.
}

(Received November 21, 2000; final form January 26, 2001)

\begin{abstract}
Kinetics of iron oxide reduction by carbon in typical stainless steelmaking slags where slag chemistry changed continuously due to dissolution of $\mathrm{Al}_{2} \mathrm{O}_{3}$ was studied. The progress of reaction was monitored by $\mathrm{X}$ ray equipment. A foamy slag formed in all cases. The foaming characteristics and the rate of reduction were dependent on the slag composition. Both chromium and vanadium oxides reduce the reaction rate. Change of slag chemistry due to dissolution of $\mathrm{Al}_{2} \mathrm{O}_{3}$ does not affect the reaction rate. The rate controlling step depends on the stirring of slag due to gas generation by simultaneous reduction of oxides.
\end{abstract}

Key Words: FeO reduction, simultareous reduction, foam formation, slag.

\section{INTRODUCTION}

The reduction of iron oxide from slag by carbon has been studied by a number of investigators /1-16/. These studies confirm that the reduction by carbon takes place by gaseous intermediates according to the following reactions:

$$
\begin{gathered}
(\mathrm{FeO})+\mathrm{CO}=[\mathrm{Fe}]+\mathrm{CO}_{2} \\
\mathrm{C}+\mathrm{CO}_{2}=2 \mathrm{CO}
\end{gathered}
$$

The rate limiting step for reduction varies with the amount of $\mathrm{FeO}$ in the slag. In high $\mathrm{FeO}$ content systems, all three types of rate controlling steps, diffusion $/ 12$, chemical reaction $/ 11,13 /$ and mixed control $/ 14 /$ have been found to be rate limiting. At lower $\mathrm{FeO}$ levels mass transport of $\mathrm{FeO}$ is reported to be the rate limiting step /11/. The reaction rate depends on the type of carbon as well. Carbon dissolved in metal reduces $\mathrm{FeO}$ in slag at a faster rate than solid carbon although the reaction mechanism remains same $19,10 \%$. All these studies except those by Görnerup $/ 15,16 /$ were on the reduction of only $\mathrm{FeO}$ from slag. Görnerup studied simultaneous reduction of iron and chromium oxides from the EAF slag and found that the reduction mechanism is not affected by simultaneous reactions.

During EAF stainless steelmaking iron oxide, chromium oxide and sometimes vanadium oxide are simultaneously reduced. Furthermore, during the progress of reaction, the slag chemistry changes due to dissolution of fluxes and lining. To understand the effect of interaction of various phenomena on the reduction of iron oxide, the present study was made where reduction of iron, chromium and vanadium

At the time of work Dr. Divakar was at the Department of Metallurgy, Indian Institute of Science, Bangalore, India and Dr. Görnerup was at Royal Institute of Technology, S-10044, Stockholm, Sweden. 


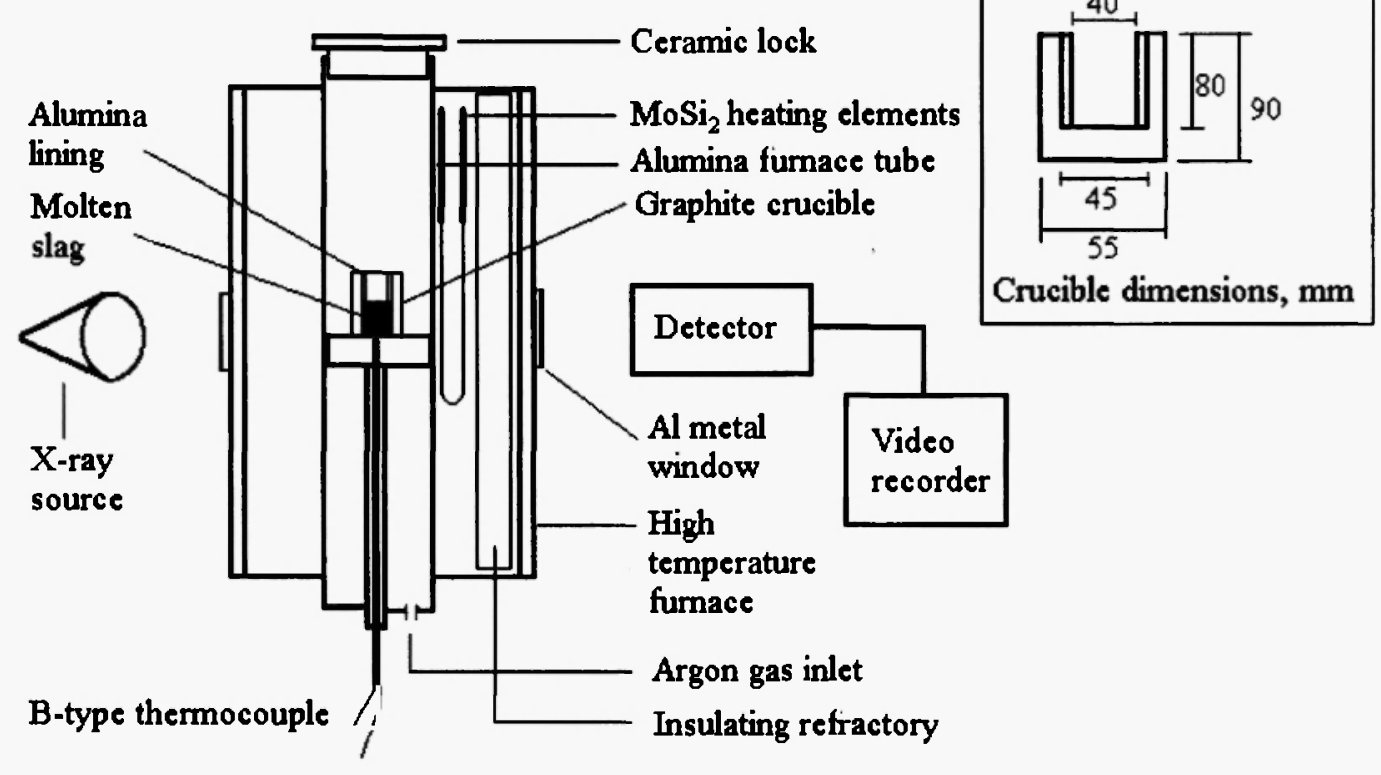

Fig. 1: Schematic diagram of the experimental setup

oxides take place along with dissolution of $\mathrm{Al}_{2} \mathrm{O}_{3}$ in the slag.

\section{EXPERIMENTAL TECHNIQUE}

The experimental equipment and procedure used in this study are similar to those presented in our earlier work $/ 17 /$. Figure 1 shows the schematic diagram of the experimental setup. The graphite crucible was lined with an alumina tube of outer diameter $45 \mathrm{~mm}$ and thickness $2.5 \mathrm{~mm}$. $50 \mathrm{~g}$ of premelted slag was used in these experiments. Table 1 lists the slag compositions that were studied. Experiments were conducted in the temperature range $1550-1650^{\circ} \mathrm{C}$. X-ray equipment along with a video recording facility was used to monitor the reduction process. In each of the experiments, the slag samples of about 0.8-1.0 g collected at different time intervals were analyzed. The respective amounts of oxides were determined assuming that weight of $\mathrm{CaO}$ in the slag remained unchanged. All slag samples were analyzed in the sequenced differentiated $x$-ray spectrometer, Siemens SRS-303. The maximum relative error when using this equipment is $\pm 2 \%$.

\section{RESULTS AND DISCUSSION}

The video recording was viewed to follow the various phenomena that occurred during the reaction. The recording showed foam and emulsion formation, variation in foam height and the gas bubble size during

Table 1

Slag Compositions Studied

Basicity $=w t \% \mathrm{CaO} / w t \% \mathrm{SiO}_{2}$

\begin{tabular}{lllllll}
\hline Basicity & $\mathrm{wt} \% \mathrm{Al}_{2} \mathrm{O}_{3}$ & $\mathrm{wt} \% \mathrm{FeO}$ & $\mathrm{wt} \% \mathrm{MgO}$ & $\mathrm{wt} \% \mathrm{Cr}_{2} \mathrm{O}_{3}$ & $\mathrm{wt} \% \mathrm{MnO}$ & $\mathrm{wt} \% \mathrm{~V}_{2} \mathrm{O}_{5}$ \\
\hline $1,1.5$ & 7 & 6 & $0,5,10,15$ & $2,5,10,14$ & 2 & $0,2,5$ \\
\hline
\end{tabular}


the reduction process. Figure 2 shows an x-ray image where the slag was lifted at certain places during the reduction process. This indicates that the gas generation did not take place uniformly at the bottom of the crucible. Figure 3 shows another x-ray image of the reduction process where gas generation is observed at the bottom and splashing is seen at the top of the slag melt. Figures 2 and 3 are typical $x$-ray pictures grabbed

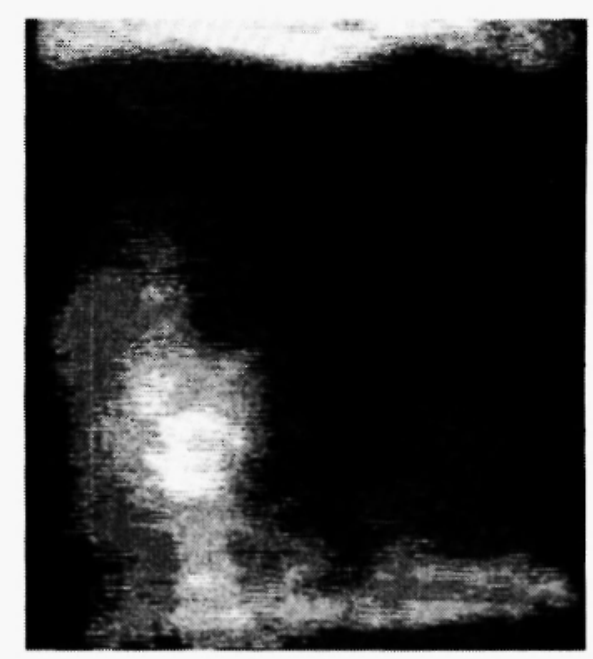

Fig. 2: X-ray image showing the lifting of the slag during the reduction of slag in a graphite crucible

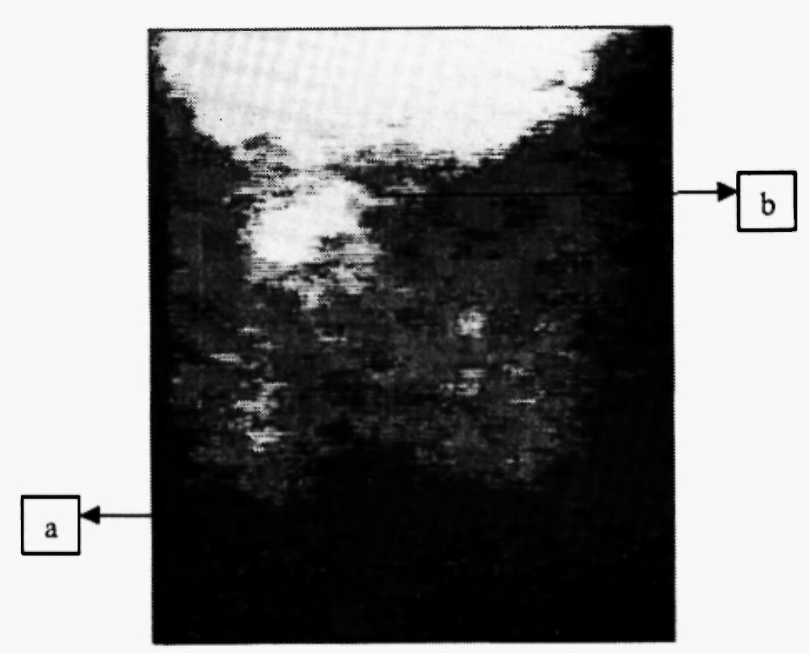

Fig. 3: $X$-ray image showing (a) gas generation and (b) splashing during the progress of the reaction from the video recording during the reduction process. It can be seen that the reduction behavior was different for different slags. The reduction of $\mathrm{FeO}$ takes place both at the metal/slag and graphite/slag interfaces. But, in this study the two processes could not be clearly distinguished. Some of the pictures clearly showed the presence of metal droplets at the bottom. So, the reaction interface was not confined to the crucible bottom.

During the reduction process, gas generation led to the formation of foam whose height changed with the progress of reaction. The height of foam was measured manually from the video recording at different time intervals. The gas generation rate and the foam height had no direct relationship.

Figures $4 \mathrm{a}$ and $4 \mathrm{~b}$ show the variation of weights of the oxides with time in one of the slag compositions studied at $1873 \mathrm{~K}$. Figure 4a shows a steep rise in $\mathrm{Al}_{2} \mathrm{O}_{3}$ content of the slag followed by a saturation stage. $\mathrm{CaO}$ and $\mathrm{SiO}_{2}$ remain unchanged in their respective weights throughout the reaction period. Figure $4 \mathrm{~b}$ shows the variation of other oxides that are grouped in the lower portion of the Fig. 4a. $\mathrm{MnO}$ and $\mathrm{MgO}$ are not reduced while $\mathrm{FeO}, \mathrm{Cr}_{2} \mathrm{O}_{3}$ and $\mathrm{V}_{2} \mathrm{O}_{5}$ are reduced. In the present experiments, the slag composition was changing continuously mainly due to the dissolution of $\mathrm{Al}_{2} \mathrm{O}_{3}$. As a first approximation, the rate of $\mathrm{FeO}$ reduction can be represented as,

$$
-\frac{d W_{F e O}}{d t}=\alpha\left(\% \mathrm{FeO}-\% \mathrm{FeO}^{e q}\right)
$$

where $\alpha$ is the apparent rate constant, $\% \mathrm{FeO}$ is the amount present at any time $\mathrm{t}$ and $\% \mathrm{FeO}$ is that in equilibrium with graphite. Equation (1) is usually written in the following manner,

$$
-\frac{W_{0} d \% \mathrm{FeO}}{d t}=\sim\left(\omega_{1} \mathrm{Fe} O-\% \mathrm{FeO} \mathrm{O}^{e_{1}}\right)
$$

where $W_{o}$ is the total weight of the slag. Since the total weight of the slag was changing in the present case, Eqn. (2) could not be used for integration. The term $\% \mathrm{FeO}^{e q}$ is very low and is neglected. Integrating Eqn. (1) from $t=0$ to $t=t$, we have, 


$$
W^{o} \mathrm{FeO}-W_{\mathrm{FeO}}=\alpha \int_{0} \% \mathrm{FeO} d t
$$

where $W_{\mathrm{FeO}}^{o}$ and $W_{\mathrm{FeO}}$ are the initial weight and weight at any time $t$ of $\mathrm{FeO}$. The right hand side of Eqn. (3) was evaluated numerically using the trapezoidal rule. The apparent rate constant can be determined by

(a)

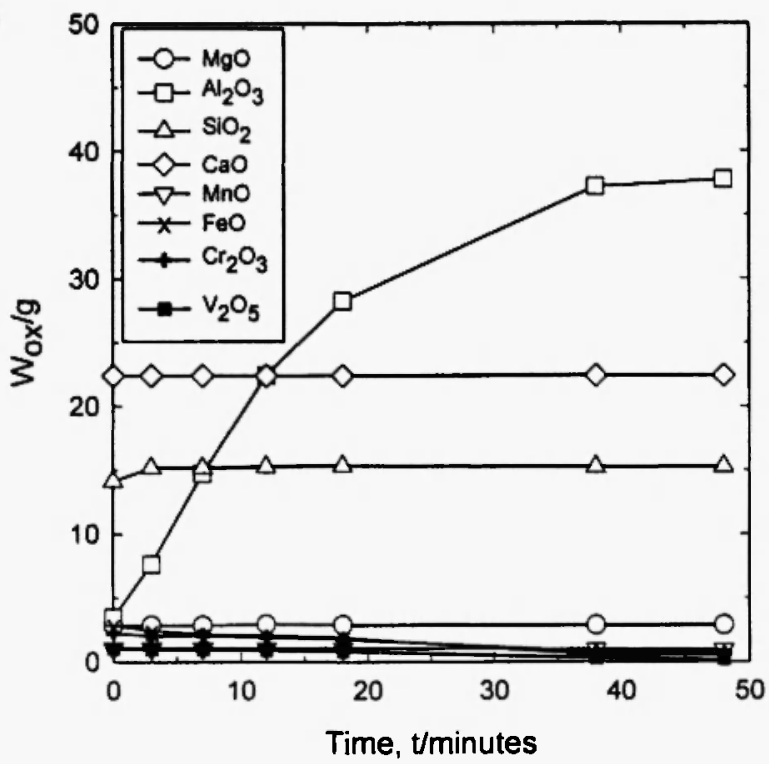

(b)

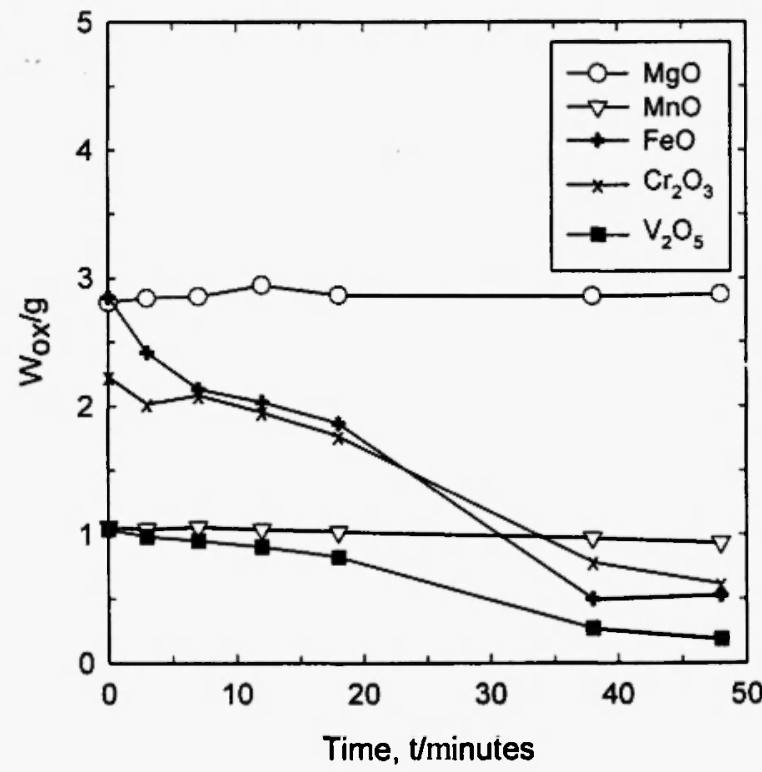

Fig. 4: The variation of slag composition during the progress of reduction for a slag containing 7\% $\mathrm{Al}_{2} \mathrm{O}_{3}, 5 \% \mathrm{MgO}, 6 \% \mathrm{FeO}, 5 \% \mathrm{Cr}_{2} \mathrm{O}_{3}, 2 \% \mathrm{MnO}$ and $2 \% \mathrm{~V}_{2} \mathrm{O}_{5}$ at $1873 \mathrm{~K}$ plotting the left-hand side term against the numerically evaluated integral. Figure 5 shows a typical plot of $\mathrm{FeO}$ reduction for different slags at $1823 \mathrm{~K}$. The reduction rates vary widely with slag compositions. All the curves are almost straight lines and the apparent rate constant was obtained by means of linear regression. This procedure is carried out at all the temperatures for a given slag composition. The rate constant $\alpha$ is directly proportional to surface area of reaction. Almost linear plots in Fig. 5 suggest that during the progress of reaction there was no significant change in the surface area of reaction. Since, except at the initial stage, reaction takes place both by carbon dissolved in metal and graphite, above observation suggests that on the whole, the total contact area of slag/metal-droplets and slag/graphite was constant. It is interesting to note that, although there was a sharp dissolution of $\mathrm{Al}_{2} \mathrm{O}_{3}$ into the slag, the rate of $\mathrm{FeO}$ reduction was not affected.

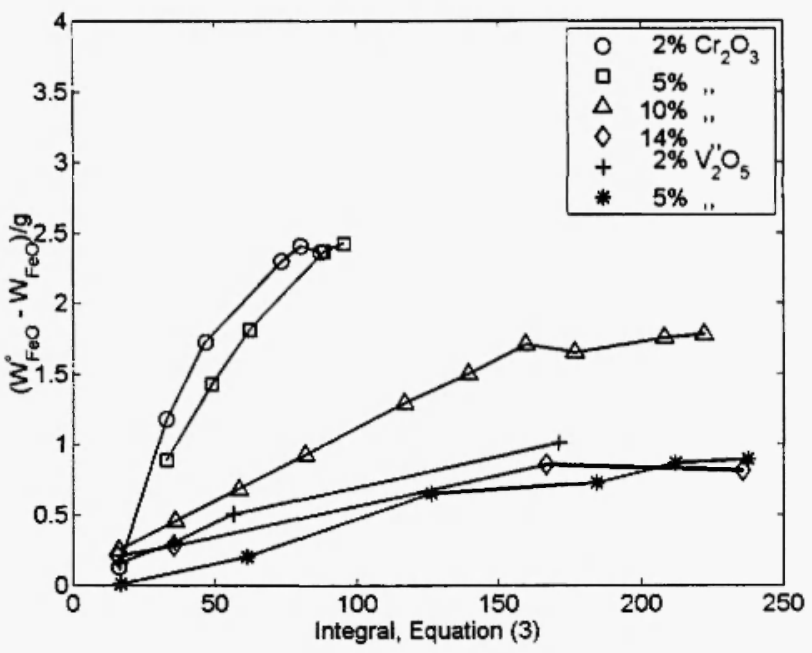

Fig. 5: Typical reduction of $\mathrm{FeO}$ in slags containing different amounts of $\mathrm{Cr}_{2} \mathrm{O}_{3}$ and $\mathrm{V}_{2} \mathrm{O}_{5}$ at $1823 \mathrm{~K}$

\subsection{Effect of Basicity}

Figure 6 shows the effect of basicity ( $w t \% \mathrm{CaO} / \mathrm{wt} \%$ $\mathrm{SiO}_{2}$ ) of the slag on the reduction rate of $\mathrm{FeO}$. The rate constants for slags having basicity 1.0 were found to be slightly higher than those having basicity 1.5. However, the effect of basicity of the slag on the reduction of $\mathrm{FeO}$ is not very significant. The effect of slag basicity on the rate of $\mathrm{Cr}_{2} \mathrm{O}_{3}$ reduction showed a similar behavior /17/. 
Contrary to the present observation Paramguru $19,10 /$ and Gornerup $/ 16 /$ reported that the rate of $\mathrm{FeO}$ reduction increases with increasing basicity up to a value of 1.5 and then decreases sharply. This anomaly can be attributed to the dissolution of $\mathrm{Al}_{2} \mathrm{O}_{3}$ or slag chemistry.

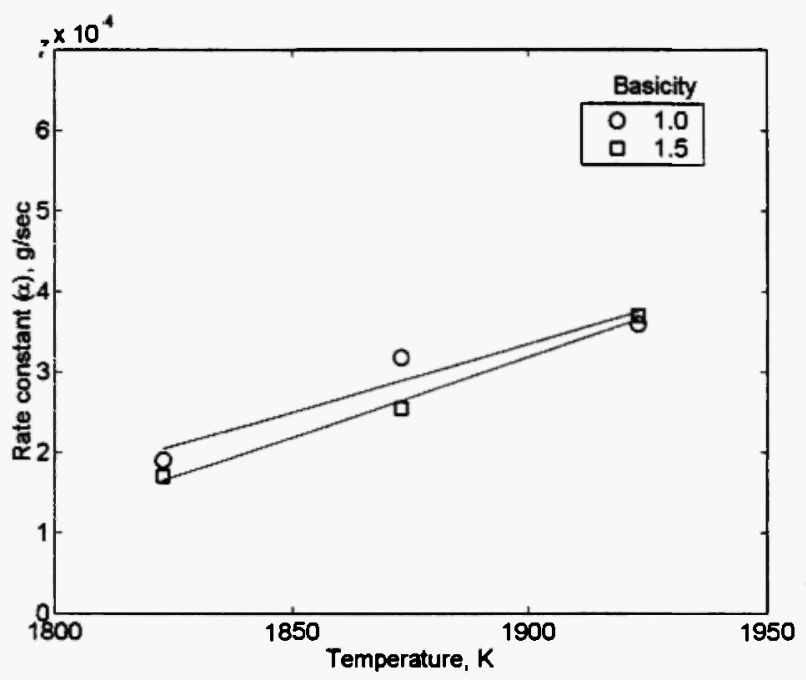

Fig. 6: The effect of basicity on the rate of $\mathrm{FeO}$ reduction with temperature. The slags contained $7 \% \mathrm{Al}_{2} \mathrm{O}_{3}, 5 \% \mathrm{MgO}, 6 \% \mathrm{FeO}, 10 \%$ $\mathrm{Cr}_{2} \mathrm{O}_{3}$ and $2 \% \mathrm{MnO}$

\subsection{Effect of $\mathrm{Cr}_{2} \mathrm{O}_{3}$ Content}

Figure 7 shows the change in the rate constant $(\alpha)$ with initial $w t \% \mathrm{Cr}_{2} \mathrm{O}_{3}$ for different slags at three temperatures. The figure shows that for each type of slag, the reaction rate decreases with increase of $\% \mathrm{Cr}_{2} \mathrm{O}_{3}$ at all temperatures. All the slag compositions contained $\mathrm{FeO}$ content in the range 5.5-5.9 wt\%. The decreased reduction rates at higher $\mathrm{Cr}_{2} \mathrm{O}_{3}$ contents of the slag can be attributed to association of the oxides in the form of spinel.

\subsection{Effect of $\mathrm{MgO}$ Content}

Figure 8 shows the effect of $\mathrm{MgO}$ content of the slag on the reduction rate at all the three temperatures. The rate falls sharply from $0 \% \mathrm{MgO}$ to $5 \% \mathrm{MgO}$ at all temperatures. The reduction of $\mathrm{Cr}_{2} \mathrm{O}_{3}$ showed a similar

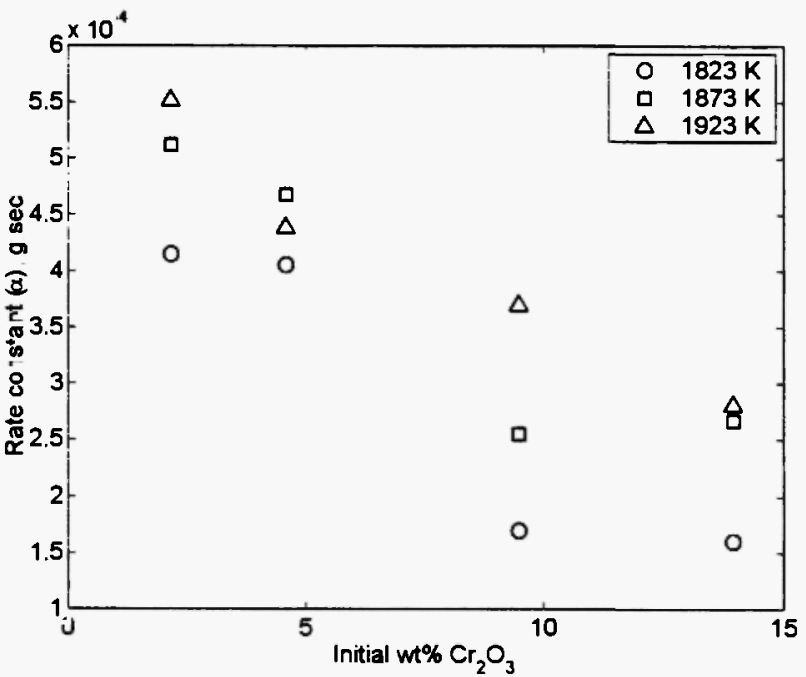

Fig. 7: The effect of initial $\mathrm{Cr}_{2} \mathrm{O}_{3}$ content in the slag on the reduction rate of $\mathrm{FeO}$ at different temperatures

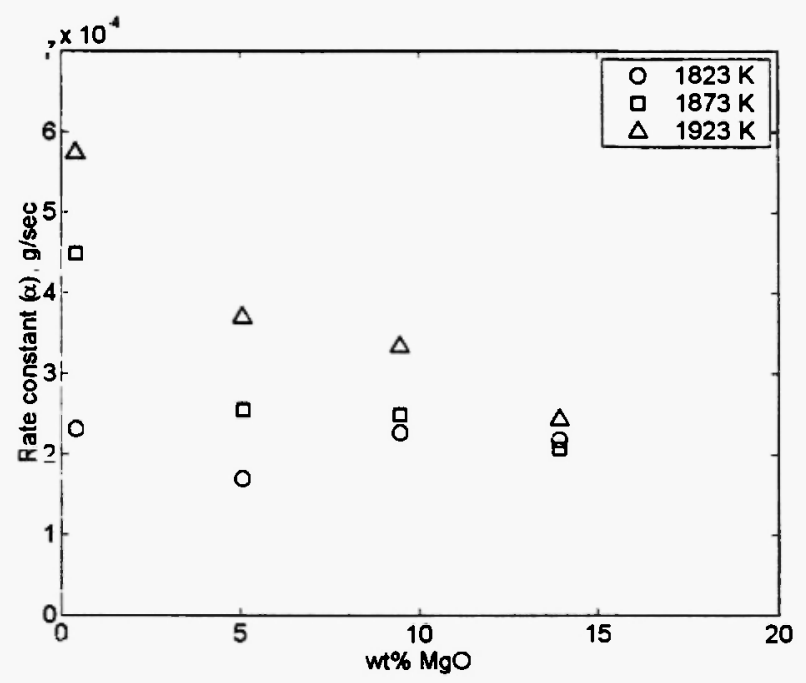

Fig. 8: The effect of $\mathrm{MgO}$ content in the slag on the reduction rate of $\mathrm{FeO}$ at different temperatures

behavior with $\mathrm{MgO}$ content of the slag as shown in Fig. $9 / 17 \%$. In the slag containing $5 \% \mathrm{MgO}$ liquid iron droplets were present at the bottom of the crucible and their size reduced with the progress of the reaction. However, in the slag containing very low $\mathrm{MgO}$ content, small droplets were found to be suspended in the foam. This suggests that the surface area for reduction was much larger in this slag than in the former. So the higher 


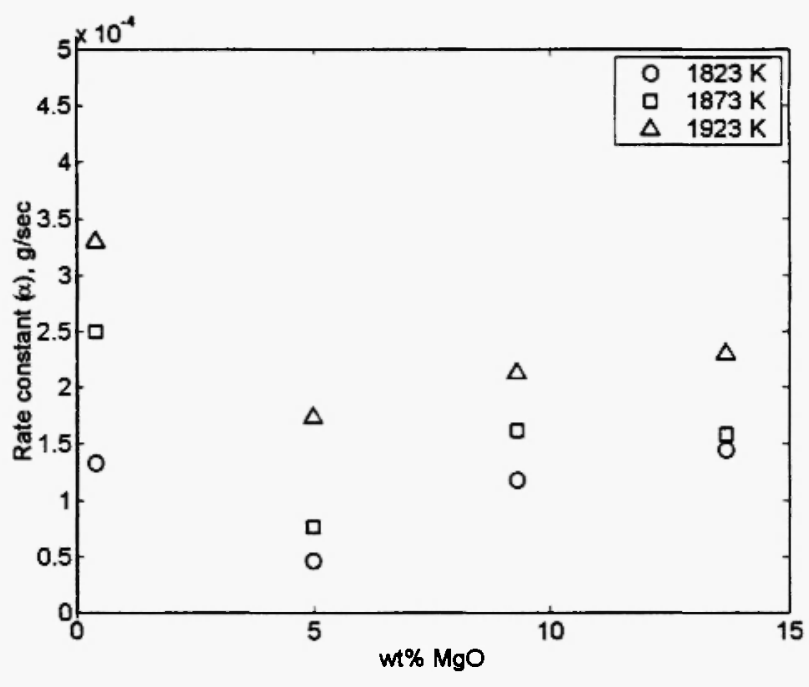

Fig. 9: The effect of $\mathrm{MgO}$ content in the slag on the reduction rate of $\mathrm{Cr}_{2} \mathrm{O}_{3}$ at different temperatures

reduction rates in Figs. 8 and 9 for slag containing very low $\mathrm{MgO}$ content may be attributed to the increase in the available surface area for reduction. Further increase in the $\mathrm{MgO}$ content of the slag did not show any definite trend in the $\mathrm{FeO}$ reduction behavior.

\subsection{Effect of $\mathrm{V}_{2} \mathrm{O}_{5}$ Content}

The rate of $\mathrm{FeO}$ reduction decreased with increasing $\mathrm{V}_{2} \mathrm{O}_{5}$ content of the slag. Figure 10 shows the effect of

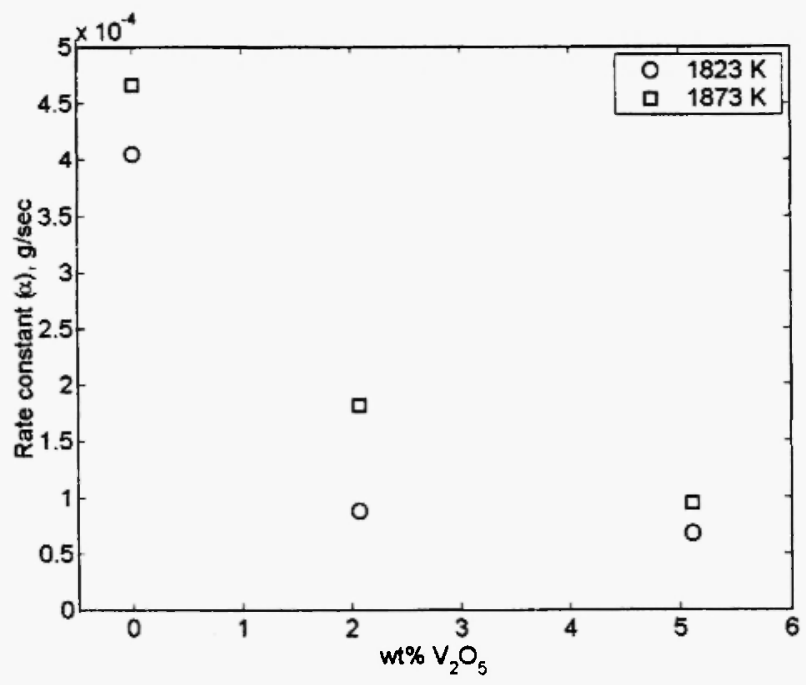

Fig. 10: The effect of $\mathrm{V}_{2} \mathrm{O}_{5}$ content in the slag on the reduction rate of $\mathrm{FeO}$ at different temperatures
$\mathrm{V}_{2} \mathrm{O}_{5}$ on the reduction rate of $\mathrm{FeO}$ at two temperatures. The rate constant decreased sharply from 0 to $2 \% \mathrm{~V}_{2} \mathrm{O}_{5}$ at both the temperatures. Further increase in the amount of $\mathrm{V}_{2} \mathrm{O}_{5}$ decreases the rate but not very sharply. The effect of $\mathrm{V}_{2} \mathrm{O}_{5}$ on the reduction rate of $\mathrm{Cr}_{2} \mathrm{O}_{3}$ from the same slag was similar $/ 17 /$. It is known $/ 18 /$ that the presence of $\mathrm{V}_{2} \mathrm{O}_{5}$, a surface-active oxide in slags, strongly promotes the formation of foam. The variation of average foam height with increasing $\mathrm{V}_{2} \mathrm{O}_{5}$ content of the slag is shown in Fig. 11 at two temperatures. The average foam height increased with increasing $\mathrm{V}_{2} \mathrm{O}_{5}$ content of the slag. A small addition of $\mathrm{V}_{2} \mathrm{O}_{5}$ to the slag leads to severe foaming thereby reducing the amount of liquid slag in contact with the reductant. This resulted in sharp decrease in the reduction rate of $\mathrm{FeO}$ (Fig. 10) from 0 to $2 \% \mathrm{~V}_{2} \mathrm{O}_{5}$. Since the compound $\mathrm{FeO} . \mathrm{V}_{2} \mathrm{O}_{5}$ is stable at high temperature, the decrease of reaction rate is partly due to association of $\mathrm{FeO}$ with $\mathrm{V}_{2} \mathrm{O}_{5}$.

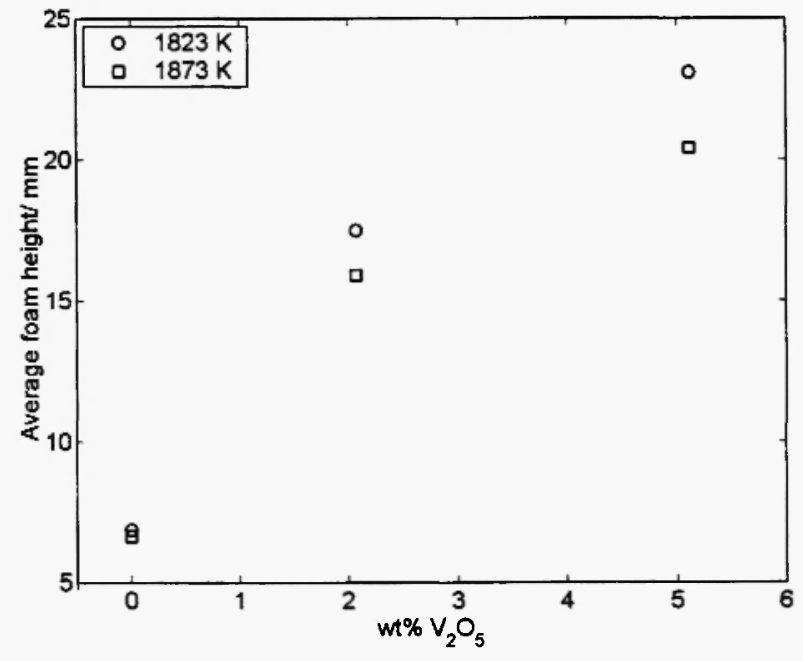

Fig. 11: The effect of $\mathrm{V}_{2} \mathrm{O}_{5}$ content on the average foam height in the slag during the reduction process at two temperatures

\subsection{Activation Energy}

Figure 12 represents the $\ln (\alpha)$ vs. $1 / \mathrm{T}$ plot of $\mathrm{FeO}$ reduction for slags containing different $\mathrm{Cr}_{2} \mathrm{O}_{3}$ levels. The activation energies in slags containing initial $w t \%$ $\mathrm{Cr}_{2} \mathrm{O}_{3}$ of 2, 5, 10 and 14 were 83, 24, 228 and 164 $\mathrm{kJ} / \mathrm{mol}$ respectively. Activation energy of $87 \mathrm{~kJ} / \mathrm{mol}$ in a slag containing $5 \% \mathrm{Cr}_{2} \mathrm{O}_{3}$ was reported in a previous 


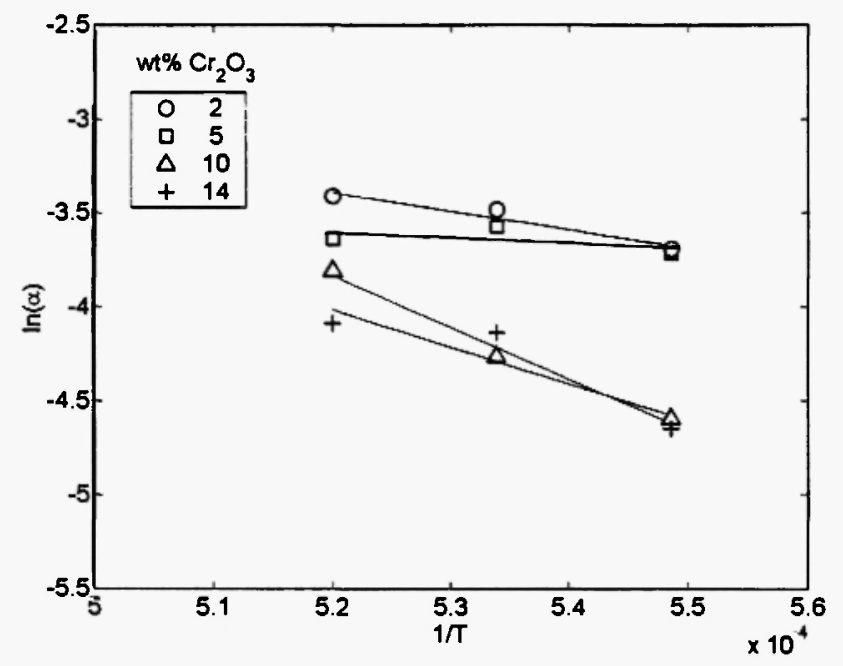

Fig. 12: The plot of In $(\alpha)$ versus $1 / \mathrm{T}$ of $\mathrm{FeO}$ reduction for slags containing different $\mathrm{Cr}_{2} \mathrm{O}_{3}$ levels

work/16/. Table 2 shows the literature data on the activation energy for $\mathrm{FeO}$ reduction, which varies between 88 and $314 \mathrm{~kJ} / \mathrm{mol}$. The present study shows that, depending on the slag composition, the activation energy lies in the range $24-579 \mathrm{~kJ} / \mathrm{mol}$.

The reported values /19-21/ for the diffusion of iron oxide in slags vary from 73 to $167 \mathrm{~kJ} / \mathrm{mol}$. The mechanism for $\mathrm{FeO}$ reduction in slags having the activation energy values in the range $70-170 \mathrm{~kJ} / \mathrm{mol}$ is the diffusion of iron oxide in the slag phase. In slags having activation energies about $40 \mathrm{~kJ} / \mathrm{mol}$ the mechanism of $\mathrm{FeO}$ reduction is the diffusion of carbon in the $\mathrm{Fe}-\mathrm{C}$ alloy phase since the reported value $/ 19 /$ for carbon diffusion in Fe-C alloys is $42 \mathrm{~kJ} / \mathrm{mol}$. Values higher than $170 \mathrm{~kJ} / \mathrm{mol}$ indicate chemical reaction or mixed controlled. Very high values of activation energy, 482 and $579 \mathrm{~kJ} / \mathrm{mol}$, obtained for $\mathrm{V}_{2} \mathrm{O}_{5}$ containing slags suggest strong association between iron and vanadium oxides in the slag.

Figure 13 shows the variation of activation energy of $\mathrm{FeO}$ reduction with average gas generation rate due to reduction at $1823 \mathrm{~K}$. The graph shows that the activation energy for $\mathrm{FeO}$ reduction decreases with increase in gas generation rate. The mixing of the slag melt during the progress of the reaction depends on the rate of gas evolution. If the mixing is intense, the length of diffusion path in the slag is low and the rate controlling step becomes diffusion of carbon in the metal phase. If the stirring intensity is less, then the reduction becomes slag phase diffusion controlled. Gas generation rate, in the present case, depends on the rates of reduction of $\mathrm{FeO}, \mathrm{Cr}_{2} \mathrm{O}_{3}$, and $\mathrm{V}_{2} \mathrm{O}_{5}$. So the presence of other reducible oxides affects the reduction rate of $\mathrm{FeO}$ both by association and by affecting the gas generation rate.

Table 2

Literature Data on the Activation Energies for FeO Reduction

\begin{tabular}{|c|c|c|c|c|}
\hline $\begin{array}{l}\text { Activation } \\
\text { Energy, } \\
\mathrm{kJ} / \mathrm{mol}\end{array}$ & Temperature, ${ }^{\circ} \mathrm{C}$ & System & Reductant & Researcher(s) \\
\hline & - & $\begin{array}{l}\text { FeO in 'slag' } \\
\text { (unknown composition) }\end{array}$ & $\mathrm{C}+\mathrm{C}$ in $\mathrm{Fe}$ & Kim et al /7/ \\
\hline 314 & & & $\mathrm{C}_{\text {steel crucible }}$ & \\
\hline 130 & $1420-1620$ & $\mathrm{FeO}(\mathrm{l})$ & $\mathrm{C}_{\text {alumina crucible }}$ & Sato et al /6/ \\
\hline 184 & & & $\mathrm{C}$ in $\mathrm{Fe}$ & \\
\hline 90 & $1200-1400$ & $\mathrm{CaO}-\mathrm{SiO}_{2}$ & $\mathrm{C}$ & Paramguru et al /9/ \\
\hline 87.9 & $1200-1400$ & $\mathrm{CaO}-\mathrm{SiO}_{2}$ & $\mathrm{C}$ in $\mathrm{Fe}$ & Paramguru et al/ 10/ \\
\hline 223 & - & $\mathrm{CaO}-\mathrm{SiO}_{2}-\mathrm{MgO}$ & $\mathrm{C}$ & Zhou $/ 8 /$ \\
\hline 135 & $1320-1600$ & $\mathrm{CaO}-\mathrm{MgO}-\mathrm{SiO}_{2}-\mathrm{FeO}-\mathrm{FeO}_{1.5}$ & $\mathrm{CO}(\mathrm{g})$ & Graenzdoerffer et al / $11 /$ \\
\hline
\end{tabular}




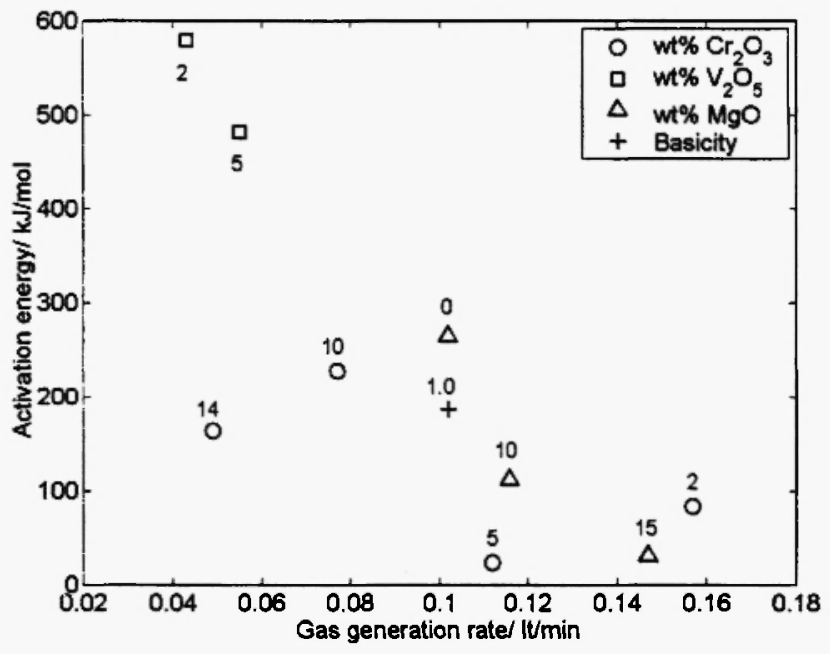

Fig. 13: The effect of average gas generation rate at $1823 \mathrm{~K}$ on the activation energy for $\mathrm{FeO}$ reduction for various slags. The base slag composition is $7 \% \mathrm{Al}_{2} \mathrm{O}_{3}, 6 \% \mathrm{FeO}, 5 \% \mathrm{MgO}$, $10 \% \mathrm{Cr}_{2} \mathrm{O}_{3}$ and $2 \% \mathrm{MnO}$, Basicity $=1.5$

$O$ : base slag with varying $\mathrm{Cr}_{2} \mathrm{O}_{3}$ content; $\square$ : base slag with varying $\mathrm{V}_{2} \mathrm{O}_{5}$ content; $\Delta$ : base slag with varying $w \mathrm{t} \% \mathrm{MgO} ;+$ : Basicity $=1.0$

\section{EFFECT OF CONTACT AREA}

The rates of heterogeneous reactions depend on the contact area between the reactants. In the present experiments several phenomena such as foaming, gas generation and lifting of the slag took place. The foam height varied with the slag composition and progress of reaction for any given slag. In some cases liquid iron droplets were suspended in the foam. Therefore, the contact area for both metal/slag and graphite/slag interfaces varied with the experimental conditions. It has already been mentioned that the lower rate of reduction of slag containing $5 \% \mathrm{MgO}$ compared to that of $0 \% \mathrm{MgO}$ is due to lower surface area for reduction. Very low activation energy value $(24 \mathrm{~kJ} / \mathrm{mol})$ for $\mathrm{FeO}$ reduction in the slag containing $5 \% \mathrm{Cr}_{2} \mathrm{O}_{3}$ appears to be due to decrease in the surface area for reduction at higher temperatures. The activation energy for reduction of $\mathrm{Cr}_{2} \mathrm{O}_{3}$ in this slag was also very low /17/ supporting the above view.

The activation energies were calculated with the assumption that the surface area for reaction is independent of temperature. The variation of activation energy with average gas generation rate shown in Fig. 13 and the values of activation energy indicate that the assumption is valid except for the slag containing $5 \%$ $\mathrm{Cr}_{2} \mathrm{O}_{3}$.

\section{CONCLUSIONS}

The surface area of reaction and rate of $\mathrm{FeO}$ reduction depend on the slag chemistry. The reduction rate decreases with increase in $\% \mathrm{Cr}_{2} \mathrm{O}_{3}$ and $\% \mathrm{~V}_{2} \mathrm{O}_{5}$ of slag. The reduction rate is not affected by the simultaneous dissolution of $\mathrm{Al}_{2} \mathrm{O}_{3}$.

The activation energies for the reduction of $\mathrm{FeO}$ range from 31 to $579 \mathrm{~kJ} / \mathrm{mol}$. The mechanism for the reduction of iron oxide depends on the intensity of stirring due to gas generation by simultaneous reduction reactions. At high gas generation rate the reduction is controlled by carbon diffusion in iron. The strong association between iron and vanadium oxides results in very high activation energies of 482 and $579 \mathrm{~kJ} / \mathrm{mole}$ in $\mathrm{V}_{2} \mathrm{O}_{5}$ containing slags. The change in the surface area of reaction with temperature can lead to very low values of activation energy.

\section{REFERENCES}

1. T. E. Dancy: J. Iron Steel Inst., 189, 17 (1951).

2. D. R. Macrae:'J. Met., 17, 1391 (1965).

3. G. W. Lloyd, D. R. Young and L. A. Baker: Ironmaking and Steelmaking, 2, 49 (1975).

4. A. Sato, R. Nakagawa, S. Yoshimatsu, A. Fukuzawa and T. Ozaki: Trans. ISIJ, 21, 879 (1981).

5. F. Tsukihasi, M. Amatatsu and T. Soma: Tetsu-toHagané, 68, 1880 (1982).

6. A. Sato, G. Aragane, K. Kamihira and S. Yoshimatsu: Trans. ISIJ, 27, (1987), 789.

7. T. D. Kim, D. J. Min and I. O. Lee: J. Korean Inst. Met. Mater., 30, 739 (1992).

8. Y. Zhou and T. Du: Acta. Metall. Sin. (China), 20, B369 (1994). 
9. R. K. Paramguru, H. S. Ray and P. Basu: Ironmaking and Steelmaking, 23, 328 (1996).

10. R. K. Paramguru, H. S. Ray, P. Basu and A. K. Jouhari: Ironmaking and Steelmaking, 23, 411 (1996).

11. G. Graenzdoerffer, W. M. Kim and A. H. Fine: Proc. of the Process. Tech. Conf., 7, Toronto, Canada, 1988; pp 137.

12. F. Fun: Metall. Trans., 1, 2537 (1970).

13. Y. Zhou and T. Du: Proc. of Int. Symp. on Smelting Reduction, Shenyang, China, September 3-5, 1986; pp 147.

14. B. Sarma, A. W. Cramb and R. J. Fruehan: Metall. Mater. Trans., 27B, 717 (1996).

15. M. Görnerup and A. K. Lahiri: Ironmaking and Steelmaking, 25, 317 (1998).
16. M. Görnerup and A. K. Lahiri: Ironmaking and Steelmaking, 25, 382 (1998).

17. M. Divakar, M. Görnerup and A. K. Lahiri: Sixth International Conference on Molten Slags, Fluxes and Salts, Stockholm, Sweden - Helsinki, Finland, 12-17 June, 2000. (Invited Paper).

18. M. Görnerup: Internal Report No. 1 (in Swedish), TO 23-59, Jernkontoret Committee JK 2315/95, Stockholm, Sweden, (1996).

19. F. Oeters: Conf. Proc. of Kinetics in Metallurgical Processes in Steelmaking, Aachen, Germany, 1975; pp 116.

20. R. F. Johnston, R. A. Stark and J. Taylor: Ironmaking and Steelmaking, 1, 220 (1974).

21. D. P. Agarwal and D. R. Gaskell: Metall. Trans., 6B, 263 (1975). 
